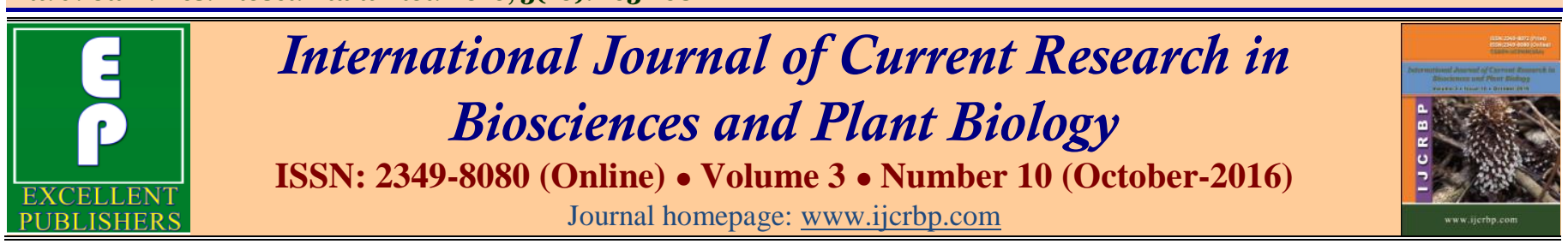

\title{
Incidence and Severity of Taro Leaf-Blight in Iwollo, South-Eastern Nigeria
}

\author{
J. O. Adinde1*, U. J. Anieke², O. G. Nwankwo², C. J. Agu'3, A. C. Aniakor3, A. A. Nwagboso² \\ and C. O. $\mathrm{Eze}^{4}$
}

${ }^{1}$ Department of Horticultural Technology, Enugu State Polytechnic, Iwollo, Enugu State, Nigeria

${ }^{2}$ Department of General Studies, Enugu State Polytechnic, Iwollo, Enugu State, Nigeria

3 Department of Agricultural Technology, Enugu State Polytechnic, Iwollo, Enugu State, Nigeria

4 Department of Agricultural Extension and Management, Enugu State Polytechnic, Iwollo, Enugu State, Nigeria

*Corresponding author.

\begin{abstract}
A b stract
Disease incidence and disease severity were evaluated to determine the prevalence of Taro Leaf Blight in Iwollo. Four cocoyam (Colocasia esculenta L. Schott) farms from each of the six villages in Iwollo namely, Umueze-Onyia, Ndibunagu, Amagu, Obinagu, Owolloti and Enugwu were randomly selected and a farm area of $8 \mathrm{~m} \times 4 \mathrm{~m}$ (32 sq m) marked out in each of the farms for the experiment. The experiment was laid out in completely randomized design (CRD) comprising six treatments with four replications. Number of plants infected with taro leaf blight was counted and the area of the affected leaves measured and used to evaluate the disease incidence and disease severity. Data collected were subjected to Analysis of Variance (ANOVA) for completely randomized design and the means showing significant difference compared using least significant difference (LSD) at 0.05 probability levels. The results revealed significant differences $(p<0.05)$ in disease incidence and disease severity among the villages in Iwollo. All the villages recorded high incidence and severity of Taro Leaf Blight with the highest percentage obtained in Umueze-Onyia village. It could be concluded from the results that there was high prevalence of Taro leaf blight in Iwollo. Good management strategies are therefore required to control Taro leaf blight and improve cocoyam production in the area.
\end{abstract}

\section{Introduction}

Cocoyam (Colocasia esculenta (L.) Schott) also known as Taro belongs to the family Araceae (Dahlgren et al., 1985). It is herbaceous plant with heart-shape leaves. It originated from Polynesia and southeastern Asia and is now grown worldwide especially in the Tropics (Kay, 1987; Wagner et al., 1999). Cocoyam is a major staple food to many people worldwide (Aguegui et al., 1992; Ooka and Brennan, 2000; Talwana et al., 2009; Onyeka,

\section{Article Info}

Accepted: 27 September 2016

Available Online: 06 October 2016

\section{Keywords}

Colocasia esculenta

Disease incidence

Disease severity

Prevalence

Taro leaf blight 
carbohydrate and income to farmers in Nigeria (Azeez and Madukwe, 2010; Chiejina and Ugwuja, 2013; Onyeka, 2014).

Cocoyam production all over the world has been threatened by a lot of diseases (Onyeka, 2014; Plantvillage, 2016). The most devastating among these diseases is Taro Leaf Blight (TLB) (Erwin and Ribeiro, 1996; Brooks, 2008; Singh, et al., 2012; Tyson, 2012; Onyeka, 2014). The disease was first described in Java by Marian Raciborski in 1900 (Wikipedia, 2016). It is a fungal disease of cocoyam (Taro) caused by Phytophthora colocasiae (Erwin and Ribeiro, 1996; Brooks, 2005; Brooks, 2008; Singh et al., 2012; Cabi, 2016). The pathogen thrives best in high humidity and high rainfall environments which aid the spread through rain splash on the free leaves (Brooks, 2005; Cabi, 2016). Affected leaves initially show small dark spots which enlarge rapidly and turn purplish brown with yellowish margins (Brooks, 2005). The lesions frequently form concentric zones and exude drops of yellowish liquid. Some of the diseased tissues may be covered with whitish fuzz consisting of sporangia (Cabi, 2016). As the disease progresses, the lesions continue to expand and frequently coalesce. Diseased tissues disintegrate, forming holes of irregular size and shape on the affected leaves. Occasionally the pathogen may cause water-soaked lesion on the petioles. Infected leaves collapse within 20 days of unfurling, compared to 40 days for healthy leaves (Cabi, 2016). The normal 6-7 leaves per plant are being reduced to 3-4 leaves per plant by severe disease incidence (Cabi, 2016).

Taro leaf blight has been recorded in a number of countries (Brooks, 2008). It has been responsible for the serious decline in cocoyam production throughout the cocoyam producing countries (Santos, 1993; Raynor and Silbanus, 1993; Brooks, 2008). The disease significantly reduces the number of functional leaves and can lead to significant reduction in yield (Jackson, 1999). In recent times cocoyam production in Africa has been threatened by the spread of Taro leaf blight (Onyeka, 2014). According to FAO (2014) reports, Nigeria is the highest producer of cocoyam with 3.3 million metric tons per annum. This rating notwithstanding, cocoyam yield in Nigeria has been affected by the recent outbreak of Taro Leaf blight. The disease has brought significant reduction in the production of cocoyam in Nigeria. Chiejina and Ugwuja (2013) reported that cocoyam production has drastically decline by $60 \%$ in Nigeria due to TLB and has reached alarming rate in Nsukka area, southeastern, Nigeria.
Iwollo is an agrarian community located in southeastern Nigeria with a good number of cocoyam farmers spread across the six villages that make up the community namely, Umueze-Onyia, Ndibunagu, Amagu, Obinagu, Owolloti and Enugwu. Since the outbreak of TLB, symptoms of the disease are observed in almost all the cocoyam farms in the area; however statistical information on the prevalence of the disease in the community is unknown. Baseline information on the prevalence of TLB in Iwollo will aid strategic planning towards managing the disease. This study was therefore aimed to determine the disease incidence and disease severity of TLB as parameters required to determine the prevalence of TLB in Iwollo, southeastern Nigeria.

\section{Materials and methods}

\section{Description of the study area}

The experiment was carried out in Iwollo from late August to early September, 2016. Iwollo is located within latitude $06^{\circ} 16.834^{\prime} \mathrm{N}$ and longitude $007^{0} 16.834$ E (Maplandia, 2016). It is 252 meters above sea level with average annual temperature range of $23.0^{\circ} \mathrm{C}-27.9$ $0^{\circ} \mathrm{C}$ (Climate-data, 2016). The rainfall pattern is bimodal from April - November with short spell in August. The average annual rainfall is $1726 \mathrm{~mm}$ (Climate-data, 2016). The precipitation varies from $9 \mathrm{~mm}$ in the driest month of December to $301 \mathrm{~mm}$ in the wettest month of September (Climate-data, 2016). Iwollo belongs to Group A (Aw - Tropical wet climate) according to Köppen-Geiger climatic classification (Peel et al., 2007). The climate is characterized by high rainfall with hot and humid conditions.

\section{Experimental design}

Completely randomized design comprising six treatments with four replications was used for the study. Four cocoyam (Colocasia esculenta var. esculenta) farms from each of the six villages in Iwollo namely, Umueze-Onyia, Ndibunagu, Amagu, Obinagu, Owolloti, and Enugwu were randomly selected for the study. An area of $8 \mathrm{~m} \times 4 \mathrm{~m}(32 \mathrm{sq} \mathrm{m})$ was marked out using marking peg and rope in each of the farms for the study.

\section{Evaluation of disease incidence and severity}

Number of cocoyam stands in each of the marked areas were counted and recorded. Stands showing symptoms of taro leaf blight (TLB) were counted and the area of the affected leaves determined. The leaf area was measured 
using non-destructive methods as described by Lu et al. (2002).

$$
\text { Leaf Area }=\mathrm{LPA} \times \mathrm{WP}
$$

Where,

LPA = leaf length from the petiole attaching point to the leaf apex.

$\mathrm{WP}=$ leaf width across the petiole-attaching point.

Disease incidence and disease severity were evaluated as described by Chaube and Pundhir (2005).

Disease incidence $(\%) \frac{\text { Number of infected plants }}{\text { Total number of plants }} \times 100$

Disease severity $(\%) \frac{\text { Area of leaves affected }}{\text { Total area of leaves }} \times 100$

A 5 point scale $(0-4$ scale $)$ as postulated by Omeje et al. (2016) was used to described disease severity (Table 1).

Table 1. Disease severity scale.

\begin{tabular}{lll}
\hline Scale & Severity range & Inference \\
\hline 0 & $<1$ & No infection \\
1 & $1-25$ & Low infection \\
2 & $26-50$ & Moderate infection \\
3 & $51-75$ & High infection \\
4 & $>75$ & Very high infection \\
\hline
\end{tabular}

\section{Identification of the causative pathogen}

Collection of samples: TLB infected cocoyam leaves were collected from the sample farms from the six villages in Iwollo. The leaves were taken to laboratory for isolation and identification of the causative pathogen.
Isolation of the pathogen: The causative pathogen was isolated as described by Adomako et al. (2016). Lesions on the cocoyam leaves were cut off using razor blade and stirred up in $10 \mathrm{mls}$ of sterilized distilled water in a Petri dish. The sporangial suspensions obtained were filtered through cheesecloth to remove leaf remnants. Sporangial suspension was mounted on a slide and observed using KYOWA TOKYO JAPAN monocular microscope at x100 magnification to identify the pathogen.

\section{Pathogenicity test}

The pathogenecity was confirmed by Koch's postulates (Byrd and Segre, 2016). Disease free cocoyam leaves were placed on sterilized filter paper soaked with distilled water and placed in Petri dishes. The leaves were inoculated with $2 \mathrm{ml}$ of sporangial suspension containing Phytophthora colocasiae as described by Adomako et al. (2016).

\section{Statistical analysis}

Data collected were subjected to Analysis of Variance (ANOVA) for completely randomized design (CRD) using GenStat Release 10.3DE software ( 2011). Treatment means with significant difference were compared using least significant difference (LSD) at 0.05 probability level as described by Obi (2002).

\section{Results}

\section{Disease incidence and disease severity of Taro Leaf blight in Iwollo}

The results of the disease incidence and disease severity of Taro leaf blight (TLB) in the six villages in Iwollo were presented in Table 2.

Table 2. Disease incidence and disease severity of Taro leaf blight in six villages in Iwollo.

\begin{tabular}{lll}
\hline Villages in Iwollo & Disease incidence (\%) & Disease severity (\%) \\
\hline Umueze-Onyia & $93.2^{\mathrm{a}}$ & $78.35^{\mathrm{a}}$ \\
Ndibunagu & $71.9^{\mathrm{cd}}$ & $62.1^{\mathrm{c}}$ \\
Amagu & $82.9^{\mathrm{b}}$ & $68.95^{\mathrm{b}}$ \\
Obinagu & $63.6^{\mathrm{d}}$ & $50.6^{\mathrm{d}}$ \\
Owolloti & $76.9^{\mathrm{bc}}$ & $57.12^{\mathrm{cd}}$ \\
Enugwu & $73.4^{\mathrm{bcd}}$ & $56.88^{\mathrm{cd}}$ \\
$L S D_{0.05}$ & 9.82 & 6.831 \\
$C V(\%)$ & 8.6 & 7.4 \\
S.E. & 6.61 & 4.598 \\
Grand mean & 77.0 & 62.33 \\
\hline
\end{tabular}

$\mathrm{LSD}_{0.05}=$ Least significant difference at $5 \%$ probability level; CV = Coefficient of variation; S. E. = Standard error; Mean values within the same column with the same letter are not significantly different $(p>0.05)$. 
The result showed significant differences $(p<0.05)$ in disease incidence and disease severity among the six villages. The highest disease incidence (93.2\%) was observed in Umueze-Onyia village while the least (63.6\%) was observed in Obinagu village. The disease incidence observed in Amagu village (82\%), Owolloti village $(76.9 \%)$ and Enugwu village $(73.4 \%)$ were statistically the same. Obinagu village which had the least disease incidence $(63.6 \%)$ was statistically at par with Ndibunagu village (71.9\%) and Enugwu village (73.4\%). Similarly, the highest disease severity $(78.35 \%)$ was recorded in Umueze-Onyia village while the least $(50.6 \%)$ was observed in Obinagu village. The least disease severity obtained in Obinagu village was statistically at par with disease severity obtained in Enugwu village (56.88\%) and Owolloti village (57.12\%). All the villages in Iwollo recorded above $50 \%$ disease incidence and disease severity. The grand mean of the disease incidence and disease severity in the six villages were $77 \%$ and $62.33 \%$ respectively.

\section{Discussion}

A laboratory study of the blighted cocoyam leaves from the six villages investigated in Iwollo, south-eastern Nigeria showed the presence of Phytophthora colocasiae. The morphology of the pathogen isolated from the infected leaves was identical to Phytophthora colocasiae as described by Cabi (2016). The pathogenicity test using Koch's postulate confirmed Phytophthora colocasiae as the causative pathogen of TLB in Iwollo. The inoculated leaves showed the same symptoms observed on the infected leaves collected from the sample farms investigated.

The results of the incidence and severity study as presented in Table 2 showed that incidence and severity of Taro leaf blight (TLB) were high in all the six villages in Iwollo. Disease severity appeared to increase with increase in disease incidence across the villages. There were significant differences $(p<0.05)$ in disease incidence and disease severity among the villages. Umueze-Onyia village with the highest disease incidence had the highest disease severity above $75 \%$ which was an indication of very high infection. Obinagu village with the least disease incidence on the other hand had least disease severity. The highest value of disease incidence and disease severity in Umueze-Onyia village was an indication of highest prevalence of TLB in the village compared to the other villages. However, all the villages recorded more than $50 \%$ in the severity scale which was an indication of high level of infection of the disease in the area. The significant variation observed among the villages could probably be due to varied agronomic practices across the villages. Umueze-Onyia village with significant higher disease incidence and disease severity probably had more favourable conditions for the disease to thrive. According to Agrios (2005) the process of epidemic is influenced by environment. The spread of TLB pathogen is influenced by agronomic practices such as plant spacing, farm sanitation and use of fungicide (Brooks, 2005). Closer spacing increases the chances of disease dissemination. Onyeka (2014) evaluated 70 farmer's field across 8 state representatives of taro growing agro-ecologies of Nigeria and reported TLB incidence range of $65 \%$ to $90 \%$ and a generally high disease severity within fields. Chiejina and Ugwuja (2013) reported similar findings and attributed significant difference in incidence of phytophthora leafblight disease of cocoyam in some sites within a location in Nsukka area to differences in agronomic practices observed by each individual farmer before, during and after planting. The source of planting material and handling could also be responsible for the significant differences observed. Asraku (2010) opined that transportation and the use of diseased planting materials represent a major means of transmitting TLB disease.

The high incidence and severity of TLB (>50\%) obtained in all the six villages in Iwollo was an indication of high prevalence of the disease in the area. This could be attributed to the climatic conditions of the area which probably favoured the spread and growth of the pathogen. Iwollo belongs to Group A (Aw - Tropical wet climate) according to Köppen-Geiger climatic classification (Peel et al., 2007; Climate-data, 2016). The climate is characterized by high rainfall with hot and humid conditions. According to Cabi (2016), TLB pathogen grows rapidly in areas with high humidity and heavy rainfall. The result could also be attributed to narrow genetic base of cocoyam cultivars in the location. Onyeka (2014) reported poor characterization of genetic diversity of cocoyam in all countries of West and Central Africa and feared that considering the ability of taro leaf blight and cocoyam root rot disease to completely destroy susceptible cultivars, there could be depletion in the diversity of cocoyam in the region. The high prevalence of TLB in Iwollo as revealed in the findings could possibly be due to the use of susceptible cultivars which probably rendered all chemical and cultural measures ineffective. Singh et al. (2012) reported ineffective management of TLB in the Pacific through chemical and cultural measures and suggested the use of disease resistance cultivars for sustainable management of the disease. 


\section{Conclusion}

The findings of the study revealed high prevalence of taro leaf blight in Iwollo. All the villages evaluated showed above 50 percent disease incidence and disease severity with Umueze-onyia village showing very high infection of taro leaf blight. With these findings management practices to combat this disease and check the epidemic are imperative in the study area. The use of disease free planting materials and disease resistance varieties are therefore recommended to control the disease and boost cocoyam production in Iwollo.

\section{Conflict of interest statement}

Authors declare that they have no conflict of interest.

\section{References}

Adomako, J., Kwoseh, C. K. Moses, E. and Larbi-Koranteng S. (2016). Prevalence of Phytophthora Leaf Blight of Taro (Colocasia esculenta (L.) Schott) in the Semi Deciduous Forest Zone of Ghana. AJEA, 11(4): 1-7.

Agrios G.N. (2005). Plant Pathology (5th ed). Academic Press, New Yolk.

Aguegui, A. Fatokun, C. A. and Haln, S. K. (1992). Protein analysis of ten cocoyam, Xanthosoma sagittifolium (L). Schott and Colocasia esculenta (L.) Schott genotypes, Root crops for food security in Africa, Proceedings of the 5th Triennial Symposium, Kampala, Uganda. 348pp.

Asraku, J. S. (2010). Identification of the major foliar fungal disease of Colocasia esculenta (L.) Schott. and its management in the Kumasi metropolis. M. Sc. thesis submitted to the School of Research and Graduate studies, Kwame Nkrumah University of Science and Technology, Kumasi, Ghana.

Azeez, A. A. and Madukwe, O. M. (2010). Cocoyam production and economic status of farming households in Abia state, South-East, Nigeria. J. Agric. Soc. Sci. 6: 8386.

Brooks, F. E. (2005). Taro leaf blight. The Plant Health Instructor. DOI:10.1094/PHI-I-2005-0531-01.

Brooks, F. E. (2008). Detached-leaf bioassay for evaluating taro resistance to Phytophthora colocasiae. Plant Dis. 92:126-131.

Byrd, A. L. and Segre, J. A. (2016). Adapting Koch's postulates. Science, 351(6270): 224-226.

Cabi (2016). Phytophthora colocasiae (taro leaf blight). Retrieved on September 8, 2016 from: http://www.cabi.org/isc/datasheet/40955

Chaube, H.S and Pundhir, V.S. (2005).Crop Diseases and Their Management. Printice - Hall of India New Delhi 11001. 703 pp.

Chiejina N.V. and Ugwuja F.N. (2013). Incidence of Phytophthora Leaf-Blight Disease of Cocoyam in Nsukka
Area of South-Eastern Nigeria. Journal of Botanical Research, 4(1):21-24.

Climate-data (2016) Climate: Iwollo-Oye. Retrieve on September 8, 2016 from: http://en.climate-data.org/ location/392666

Dahlgren, R. M. T., Clifford, H. T. and Yeo, F. T. (1985). The Families of the Monocotyledons: Structure evolution and taxonomy. Springer-verlag, New York, USA, 520 pp.

Erwin, D. C. and Ribeiro, O. K. (1996). Phytophthora Diseases Worldwide. American Phytopathological Society Press, St. Paul, MN.

FAO (2014) Faostat. Retrieve on September 8, 2016 from: http://faostat.fao.org/

GenStat Release 10.3DE (2011). Discovery Edition 4 VSN International Ltd. Rothamsted Experimental Station, Howel, Hempstead, UK.

Jackson, G. V. H. (1999). Taro leaf blight. Pest Advisory Leaflet (No. 3). Plant Protection Service, Secretariat of the Pacific Community. 2pp.

Kay, D.E. (1987). Crop and product digest No. 2 Root crops. Tropical Development and Research Institute, London. 245pp.

Lu, H. Y., Wei, M. L., Lu, C. T., and Chan, L. F. (2002). Comparison of Different Models for Non-destructive Leaf Area Estimation in Taro. Journal of Agronomy, 96:448453.

Maplandia (2016). Iwollo-Oye. Retrieved on September 8, 2016 from: http://www.maplandia.com/nigeria/enugu/ ezeagu/iwollo-oye.

Obi, I.U (2002) Statistical Methods of Detecting Differences Between Treatment Means and Research Methodology Issues in Laboratory and Field Experiments Ap. Express publication Company, Nsukka, Nigeria. 117pp.

Omeje, T. E., Ugwuoke, K. I., Adinde, J. O., Ogwulumba, S. I. and Unigwe, L.O. (2016). Effect of cropping season on the control of Taro Leaf Blight (Phytophthora colocasiae ) of cocoyam (Colocasia esculenta L.) in Nsukka, south eastern Nigeria, I.J.A.B.R, 6(1): 30-39.

Onwueme, I. C. (1994). Tropical root and tuber crops Production, perspectives and future prospects. FAO Plant Production \& Protection Paper 126. FAO, Rome. 228 pp.

Onyeka, J. (2014). Status of Cocoyam (Colocasia esculenta and Xanthosoma spp) in West and Central Africa: Production, Household Importance and the Threat from Leaf Blight, Lima (Peru). CGIAR Research Program on Roots, Tubers and Bananas (RTB). Available online at: www.rtb.cgiar.org

Ooka, J. and Brennan, B. M. (2000). Crop Profile for Taro. Hawaii College of Tropical Agriculture and Human Resources, University of Hawaii-Manoa. 2pp.

Peel, M. C., Finlayson, B. L. and McMahon, T. A. (2007). Updated world map of the Köppen-Geiger climate classification. Hydrol. Earth Syst. Sci. 11: 1633-1644.

Plantvillage (2016). Cocoyam. Retrieved on September 8, 2016 from: https://www.plantvillage.org/en/topics/cocoyam

Raynor, B., and Silbanus, S. (1993). Ecology of Colocasia taro production on Pohnpei. In: Proceedings of the Sustainable 
Taro Culture for the Pacific Conference, University of Hawaii, Honolulu, Hawaii. HITAHR. Research Extension Series No. 140: 20-24.

Santos, G. H. (1993). Colocasia taro varieties on Pohnpei. In : Proceedings of the Sustainable Taro Culture for the Pacific Conference, University of Hawaii, Honolulu, Hawaii. HITAHR Research Extension Series No. 14: 8-14. Singh, D., Jackson, G., Hunter, D., Fullerton, R., Lebot, V., Taylor, M., Iosefa, T., Okpul, T., and Tyson, J. (2012). Taro leaf blight - a threat to food security. Agriculture. 2: $182-203$.

Talwana, H. A. L., Serem, A. K., Ndabikunze, B. K., Nandi , J. O. M., Tumuhimbise, R., Kaweesi, T., Chumo, E. C. and Palapala, V. (2009). Production Status and Prospects of
Cocoyam (Colocasia esculenta (L.) Schott.) in East Africa. Journal of Root Crops, 35 (1):98-107.

Tyson, J. (2012). Taro Leaf Blight: A Threat to Food Security. Agriculture 2:182-203.

Wagner, W. L., Herbst, D. R. and Sohmer, S. H. (1999). Manual of the Flowering Plants of Hawaii. Revised edition. Vol. 2. University of Hawaii Press/Bishop Museum Press. p.1357.

Wikipedia (2016). Taro Leaf Blight. Retrieved on September 8, 2016 from: https://en.wikipedia.org/wiki/Taro_leaf_blight

Wills, H. B. R., \& Lim, K. S. J. (1983). Nutrient composition of taro (Calocasiae esculenta) cultivars from the Papua New Guinea highlands. Journal of the Science of Food and Agriculture, 34(10), 1137-1142.

\section{How to cite this article:}

Adinde, J. O., Anieke, U. J., Nwankwo, O. G., Agu, C. J., Aniakor, A. C., Nwagboso, A. A., Eze, C. O., 2016. Incidence and severity of taro leaf-blight in Iwollo, South-Eastern Nigeria. Int. J. Curr. Res. Biosci. Plant Biol. 3(10), 163-168. doi: http://dx.doi.org/10.20546/ijcrbp.2016.310.020 